\title{
Resolving the Paradox of the Enlightenment
}

\author{
Sergey Tyulenev* \\ School of Modern Languages \& Cultures \\ Durham University \\ Elvet Riverside, New Elvet, Durham DH1 3JT, UK
}

Received 26.11.2014, received in revised form 04.12.2014, accepted 20.01.2015

The focus of this article is on the role of translation in the Westernisation of eighteenth-century Russia. The emphasis is placed on the integration of Russian science into the European global science function system (Luhmann). In the global science system, translation played a part in resolving the paradox of the Enlightenment agenda, which was how to make possible the exchange of knowledge in the scholarly community (mainly in Latin), and at the same time make that knowledge accessible to any other, nonacademic, linguistic community (in Russian). Reports of the Saint-Petersburg Academy of Sciences, Russian renderings of scientific terminology and non-verbal scientifically relevant phenomena are analysed as examples.

Keywords: translation science, Russia, eighteenth century, Luhmann.

Research area: philology.

It is as if he [Vasilii Tatishchev] lived in two worlds-Russia, his political and physical world [...]; and Europe, the West, his mental world, the world of scholarship, which had its inviolable rules of objectivity and contempt for petty national differences and boundaries $[\ldots]$

Herbert Leventer (1972:7)

\section{The Three Aspects of the Westernisation of Eighteenth-Century Russia}

In the eighteenth century, after a long period of being almost completely cut off from the rest of Europe, the Russian Empire made a turnabout and opened itself up to the Reformation along Western European lines. This process is usually referred to as Westernisation or Europeanisation. Both terms, however, fail to express the complex dynamics of the process, the following three aspects of which should be singled out: (1) Russia borrowed from Europe; (2) Russia projected information about itself into Europe; (3) Russia endeavoured to become part of the European global function system. The terms Westernisation and Europeanisation reflect only Aspect (1). In what follows, I will consider the Westernisation of Russia in the terms of social systems theory (SST) developed by Niklas Luhmann (1927-

(c) Siberian Federal University. All rights reserved

* Corresponding author E-mail address: sergeytlnv@gmail.com 
98), because it makes it possible to show the relationship between the eighteenth-century Russian Empire and Western Europe in a fuller way.

In Luhmannian terms, Russia may be described as a social system, surrounded by an environment (Tyulenev 2012b). Western Europe was a part of this environment. Russia as a social system had its own communication, that is, the social characteristics that made it different from any other empire or nation. Put differently, Russia operated in its own way, and in this sense it was an operational closure.

Yet, as a system, Russia was not isolated from, but was interactionally open to its environment. The interaction went both ways: from and into the system. Aspect (1), as defined above, reflects Russia's receiving from Western Europe, and the terms Westernisation and Europeanisation reflect this direction. They fail, however, to reflect Aspect (2). At this point in its history, the Russian Empire informed Western Europe about the radical changes that it was experiencing, the changes that turned Russia from an obscure 'savage' Muscovy into a European nation.

Aspect (3) requires a more detailed explanation. Modern society operates as a function-based system. Advanced degrees of differentiation were achieved between the inner subsystems of modern European societies (subsystems such as religion, politics and the economy). European countries have evolved into combinations of functionally differentiated subsystems. Each function system has become an operational closure sui generis. Operations within the political subsystem, for example, are distinct from operations in the other social subsystems (law, religion, science, art), which form the environment of the political subsystem. The economic subsystem also functions differently from any other subsystem in its environment. Science is yet another subsystem with its respective environment. In other words, every such subsystem proclaims the primacy of its function as the basis of its operation.

(In what follows, science is referred to as either a system or a subsystem. When science is described in relation to the larger social body, e.g., Europe or the Russian Empire, it is termed a 'subsystem' (being a part of a system). When science is treated as a social body in its own right, e.g., as a function system with no further reference implied, it is called a 'system'.)

Functional differentiation leads to the formation of a new type of the overall social system. This system is characterised by an unprecedented degree of complexity, and the boundaries of its subsystems cut across national territorial frontiers. The only exception is the political subsystem. It operates within "states", which are units that optimise its social functioning. Other subsystems spread over the globe. In the eighteenth century, they embraced only Europe. In Europe, economic patterns, scientific pursuits, mutually enriching aesthetics became international, territorial boundaries working only for politics (Luhmann 1990: 178). For example, the only meaningful boundary of science was the boundary between its operation and those of all the other types of operation, observed in the other function systems-science vs. non-science, for example, politics, religion etc. By the period of the Enlightenment, scientific communication had developed into an all-European structure. Scientific ideas could not have been confined within any political-territorial frontiers. When modern society is seen as being based on functions - in Luhmann's SST - it is referred to as a global social function system.

Luhmann traces the beginning of the new social system in Europe back to the late medieval period (1997: 708 sq.). Russia was introduced into this global system no earlier than the sixteenthseventeenth centuries. In the eighteenth century, 
with the beginning of Peter the Great's reforms aimed at the Westernisation of his empire, the integration of Russia into the European global system gained full momentum.

\section{Translation}

\section{As a Boundary Phenomenon}

Translation was considered by Peter and his heirs to the Russian throne, especially Catherine the Great, to be a highly important method of introducing European values into the system (see Aspect (1) above): numerous Western European publications were translated into Russian, and Western European technical know-how and knowledge were also borrowed. Translation was also recognised as a tool that could be used to inform the environment about Russia and its progress (see Aspect (2) above): numerous publications about Russia were translated and circulated in Europe. Yet translation also became an indispensable mechanism for integrating Russia into the European global system. This aspect of Russian Westernisation, if we choose to use the established term, corresponds to Aspect (3), and is the focus of the present paper. More specifically, I will concentrate on the role of translation in the process of Russia's integration into the subsystem of science: I will consider the role which translation played in making Russian science part of European science.

Translation is a social activity. This means that it is determined by the social conditions under which it takes place. Elsewhere (2012a: 146-57), I have argued that translation may be seen as a boundary phenomenon of the social system. Translation either opens or closes the system. Translation introduces various phenomena of the environment into the system and thereby opens the system. It may also reject (leave out/not translate) certain components of the source texts or cultural phenomena. When a text is translated, it is inevitably transformed. The transformation is not only linguistic; it is also social, cultural and ideological. When translation 'sifts' the translated phenomena, it closes the system. This, in a nutshell, is how translation functions as the boundary of the social system.

One should be careful not to reduce the notion of systemic boundaries to that of territorial boundaries, such as the frontiers of nation-states. Geopolitical frontiers are only one example of systemic boundaries. For instance, the function systems of science and the economy are also separated by boundaries. When scientific notions are expressed in economic terms (e.g., how much would a certain type of research cost?), the two systems interact across a boundary, because each of them operates on its own terms and their interaction will require a translation (re-coding) of features of the scientific system into features of the economic system and vice versa. Such translation will serve as a boundary phenomenon, transforming the notions of the source system into the notions of the target system.

Importantly, in this paper, translation is not seen as mere verbal transformation; rather, verbal translation is considered to be only one type of mediated transfer. Translation is here understood as a boundary phenomenon, mediating the interaction between the system and its environment, or between subsystems within one system, e.g., science and the economy.

This definition of translation prompts us to reconsider the place and function of translation in a global system, such as eighteenth-century Europe. Translation was also inevitable there because there were different languages: Latin, Greek, vernaculars. Translation was necessary for uniting all 'national sciences' into one 'common European science'. Greek (mainly in terminology) and Latin were used not only by force of tradition but also because they each had a developed terminology which vernaculars lacked. Yet Latin and Greek made science elitist. This contradicted 
the universalist ethos of the Enlightenement. Therefore, translation was needed not only in order to overcome linguistic differences, but also to create a common international scientific space on the one hand, and to make knowledge universally accessible within different linguistic communities on the other. In other words, translation had to mediate between different vernaculars and the traditional lingua francas of science of the time-Greek and Latin, and between the scientists of different countries and the scientists and the general public. Translation of scientific texts from vernaculars into Latin within the science as a function subsystem of the European global system helped scientists who spoke different languages to communicate more effectively. Translation into Latin was also a way of ensuring the terminological exactness of the scientific discourse, which is the hallmark of scientific communication.

The spread of scientific ideas within nationstates, however, required vernaculars. To make science accessible to the general public, scientific texts had to be translated from Latin. Translation was called upon to reconcile the two mutually contradictory tendencies.

\section{Negotiating a Way}

An example of this is found in the journal of the Saint-Petersburg Academy of Sciences in the first century of its existence. The Decree establishing the Academy was issued in 1724 by Peter the Great. The actual opening of the Academy took place in 1725 . The reports, minutes of academic activities and the academics' work were published in Latin, Russian, German and French (Pekarskii 1870: vol. 1, pp. V-VI). The journal of the Academy was first published in Latin and made the work of the Saint-Petersburg Academy accessible to European scientists, but less so to the general Russian readership (Pekarskii 1870: vol. 1, pp. LX-I). Nartov, who was appointed to replace Schumakher as the head of the Academy in 1742, suggested translating the Academy's Commentarii into Russian with the following argumentation: "Only one volume of Commentarii was translated into Russian in 1728 for the sake of the Russian people, and all of its copies were sold out. No more volumes were translated into Russian, but were printed only in Latin, from which those Russians who did not know Latin could not benefit" (translated by me from the quotation in Pekarskii 1870: vol. 2, pp. XIII-XIV).

Russian library catalogues (notably, in the Academy of Sciences, Luppov 1976: 352-3) were translated into Latin. The reason was, once again, that Russia wanted to make its book and manuscript collections accessible to the global science system which it aspired to join.

For some time, in Russian higher education, arts and sciences had been taught in Latin. Latin was a prevalent medium not only in the science subsystem but also in the subsystem of education. For example, lectures at the University were delivered in Latin.

According to the Charter of the Academy of Sciences, the lecturing professor's adjunct had to be also his interpreter (Novi 1750: 18). In 1746, for the first time in the history of Russian university teaching, Lomonosov began lecturing in Russian (Koshtoianz 1948: 42-3), although lecturing in Russian was out of the question for the foreign members of the Academy (for the simple reason that their command of Russian was very limited). The translated version of the lecture ensured students' understanding.

Even at the stage of planning the university in Saint-Petersburg, one of Peter's preoccupations was to ensure Russian students' full understanding of their foreign lecturers. For this purpose, he gave the order that students from the University of Vienna who spoke the Slavic languages and therefore would be able to translate 
lectures at the University of Saint-Petersburg for Russian students be found (Pekarskii 1870: vol. 1, pp. XXX-I).

However, addressing the European scholarly community was also a goal of the Academy. Making science accessible to the Russians was the other, and the Russians were to be addressed in their own tongue. The invitation to the first assembly of the newly established Academy on December 27, 1725, was published in both Latin and Russian, although the Russian version was a translation from the Latin original (Pekarskii 1870: vol. 1, pp. XXXVII-VIII). Originally, the reports and papers of the Academy had not been published in Russian (with the exception of one volume in 1728), but the rationale for a new series, Novi Commentarii, launched in 1750, was as follows:

Надлежит читателю и о том ведать, что сие содержание ученых рассуждений... сочинено особливо для Российского народа, чтоб оному во удовольствие любопытства яснее понять можно было, в чем именно авторы сих рассуждений о приращении наук полагали старание.

[The reader should also know that the contents of the scholarly discussions were written specifically for the Russian readers, so that they would have the pleasure of a clear understanding of the domains in which the authors of these notes strived to increase knowledge] (pp. 6-7).

The first 88 pages of the volume were in Russian and they contained the Charter of the Academy of Sciences and Arts, signed by Empress Elizaveta on 24 July, 1747. After that, extracts of the presentations, made by the academics, were published also in Russian. Starting from page 89 (with a new pagination), the full Latin version (500 pages with 17 Tables) followed. Latin was the language of science, whereas Russian translations of academic reports and papers were meant to make science available to the Russian readership. In all these cases, Latin had priority, the Russian texts being translations from the Latin originals. The Russian language bridged the gap between academic knowledge and the general public. This was specifically addressed in the Charter of the Academy. For example, according to Article 1, one of the tasks of the Academy was to conduct research and publish its results for the general public (Novi 1750: 14: “... познавать и разыскивать различные действия и свойствы всех в свете пребывающих тел,.. а потом... издавать в народ" [...to study different actions and properties of all things existing in the universe and then publish them for the people]). In Articles 2-4, it was emphasised that the academics of different departments should contribute to the prosperity of the state (ibid.: 14-15).

The language policy pointed to the preference for Latin or Russian over German or French. In Article 19, it was said that all activities (including publishing the journal of the Academy) were to be conducted either in Latin or in Russian, French and German were excluded (ibid.: 21-2: “...и журнал, и все что в собрании Академиками отправляться имеет, должно писано быть на Латинском или Российском языке, а Французской и Немецкой никогда употреблен быть там не должен"). This was, however, changed later. For example, in succeeding editions of the Academy journals, under some articles in French, we find footnotes "traduit du Russe" (Acta 1780: 3). In Acta 1781, we read the following report about an academic assembly:

S.E. Mr. de Domaschnef, Directeur président à l'Assemblée, publia avec des regrets dus à leurs mérites les 
noms de Académiciens honoraires \& externs morts pendant le cours des deux derniers années. Il proclama ensuite six nouveaux membres, que l'Académie pour réparer la perte des premiers, avoit élus dans sa Séance du 28 Septembre. S.E. Mr. d'Adadourof, Conseiller privé actuel et Sénateur, qui étoit du nombre, fut introduit par le Secrétaire, \& après pris place parmi les Honoraires, il adressa à l'Académie un discours de remerciment en russe, auquel Mr. de Domaschnef répondit dans la même langue (p. 4).

In this extract, the event is told in French. The name "Domaschnef" is spelt with a trace of German: the Russian sound 'sh' is rendered as 'sch' and not as the French 'ch' (cf. the name of the river Irtysh is rendered in French as "l'Irtiche" (Acta 1780: 6, 13). The Russian language is only mentioned as having been used. This passage shows that although Russian was used in the Academy, the Acta were written partly in Latin, partly in French, not in Russian, as Novi 1750 required. Obviously, the language policy had changed. Translations were from Russian into Latin or French, and as a result the interests of the Russian readership were not always a priority. The German spelling of the Russian academic Domashnev probably reflects the usual way of transliterating the name by German members of the Academy. Russian was used in the Academy, as is clear from the above quoted materials, although it was not always the language of published proceedings. Since academics, professors and their students used Latin, Russian, French and German, translation must have been an internal necessity within the Academy and its subordinate institutions: for example, adjuncts' translated lectures or translations were used in the Academy's assemblies (Pekarskii 1870: vol. 1, pp. XLI, XLII). Translation mediated between the
Academy and the Russian public; it also ensured the Academy's integration into the European scientific community.

Thus, translation was called upon to reconcile the two conflicting tendencies, the two mutually exclusive universalist pursuits: to make 'Russian' knowledge available to the whole of Europe and at the same time to make knowledge available to Russians who did not speak Latin, French or German. Yet the process was far from beneficial from the Russian general public's point of view: sometimes it seems to have been forgotten. This indicates that the integration into the European function system was for Russian science more important than its universalist claims.

\section{Terminology: Translation Suggested}

With the general picture in mind, let us examine how translators managed to render scientific ideas into a language without a welldeveloped terminology or abstract scientific and scholarly vocabulary. Indeed it was a formidable task. For one Russian translator it even proved fatal. At one point, the translator Volkov was Peter the Great's envoy to Constantinople, Paris and Venice. When he returned to Russia, Peter commissioned him to translate from French a book entitled Le jardinage de Quintiny. The book contained numerous horticultural terms which completely baffled the translator. His despair led him to cut his arteries (Pekarskii 1862: 226). Fortunately, this was the only such case known.

Translation of scientific texts into Russian produced several possible renderings of borrowed terms (from Latin, Greek or contemporary languages). Over time, one or two terms would be selected out of the originally offered series. In other words, translation offered options and the system took its pick.

Borrowing occurred between Latin and a vernacular $(\mathrm{L} \Leftrightarrow \mathrm{V})$, between Greek and a 
vernacular, often through Latin and/or another vernacular $(\mathrm{G}[\Rightarrow \mathrm{L} \Rightarrow \mathrm{V} \Rightarrow] \mathrm{V}), \quad$ or between vernaculars $(\mathrm{V} \Leftrightarrow \mathrm{V})$. Let us note that terms were created not only in vernaculars, but also in the scientific Latin. It was indeed an exchange: $\mathrm{L} \Leftrightarrow \mathrm{V}$.

Before I analyse in detail Russian borrowings from Latin, it will be useful to look at an example of borrowings from Russian into Latin and other vernaculars. The Russian scientist Ivan Lepekhin (1740-1802) discovered several plants and insects, which were named after him in Latin and thus accepted by the entire international scientific community (Lukina 1965: 55). His surname was Latinised and used as the second component of the Latin terminological compounds: for instance, Chrysomela Lepechini and Gryllus Lepechini. The transliteration Lepechini is an example of translation from a vernacular, Russian, into Latin, the international scientific medium: $\mathrm{V} \Rightarrow \mathrm{L}$. The genus part (in Latin) of the terminological biological compound was appended with a Latinised vernacular part (species): Chrysomela + Lepechini.

Geographical names are another example of the Russian contribution to European knowledge. Russian geographical names were introduced in their foreignised forms, depending on the language of the publication. The following are examples in French: "des îles de Nova-zemlia," "une branche du grand sistème des Alpes de l'Asie, laquelle en s'étendant depuis l'Irtiche jusqu'à l'océan oriental, prend des noms divers comme ceux d'Altai, Telezkoi, Savanskoi \& Stanovoi Chrêbet" (Acta 1780: 5, 6; my emphasis).

Terminological contributions through transliterations of Russian names, personal or geographical, were, however, relatively rare. Much more significantly, translation contributed to Russia's integration into European science through rendering into Russian foreign books and treatises. In the rest of this section, I will consider the contribution of translation to creating Russian scientific terminology. As an example, I will analyse renditions into Russian of the terminological series with the meaning liquid/ humidity. This series provides a comprehensive illustration of how many options translation could offer for the system to select from. Originally, different translations suggested the following series of terms: mokrota (Polikarpov 1982: 359; Weismanns 1982: 195), mokrotnost' (Polikarpov in Kutina 1966:159), mokrost' (Polikarpov 1988:359), vlazhnost' (Polikarpov 1988: 113; Weismanns 1982: 195), vlaga (Polikarpov 1988: 112; Weismanns 1982: 195), likvor (Polikarpov in Kutina 1966: 133 and Kantemir 1868: 423), flegma (Polikarpov 1988: 724), volglost' (Weismanns 1982: 195), zhidkost' (Kutina 1966: 159, 161) and syrost' (Weismanns 1982: 195). The series included both borrowings and Russian words. It is possible to see various patterns of rendering foreign terms as a means of bridging the gap between Russia and Western European science. (Unlike linguistic-historical studies, such as Huettl-Worth 1956; Kutina 1966; Birzhakova, Voinova, Kutina 1972; Smith 2007, my aim is rather to illustrate the major types of translation of foreign terms, which is why I will concentrate on only one 'proto-terminological' series - liquid/ humidity - since this series provides an excellent illustration.)

With the exception of the words likvor and flegma, the series is composed of Russian synonyms (comparable to the English synonymic set 'humidity, dampness, wetness, dankness, moisture, liquid'). We will begin with one of the first dictionaries published in Russia in the eighteenth century - Leksikon Treiazychnyi (Trilingual Dictionary, 1704). The compiler of the dictionary, Fedor Polikarpov (1670-1731), juxtaposed Russian words with their Greek and Latin equivalents: in some cases he provided the equivalents in the three languages already in use 
and in some cases, when none were known, he found or even created Russian equivalents for Greek and Latin terms.

He explained that he modelled his dictionary on the New Testament triglossia of Hebrew, Greek and Latin, but replaced Hebrew, less useful for his contemporaries, with Russian (Polikarpov 1988: 4). Polikarpov's dictionary draws on translational traditions of the second half of the seventeenth century, especially on those of the Greco-Slavonic school in which Polikarpov was raised as a scholar (Polikarpov 1988: VI). In the practices of Polikarpov, we can see what we also observe with later eighteenthcentury translators: before making a decision they considered the existing work of their colleagues and predecessors. In Luhmannian terms, this practice is what can be described as ensuring the continuity of the communication that was taking place in the emerging subsystem of Russian science: translators did not act as independent individuals, rather they stood on the shoulders of their predecessors and carried on the systemic communication.

For Greek and Latin terms with the meaning humidity/liquid, Polikarpov supplied as equivalents the Russian words mokrota, mokrost' (and their corresponding adjectives mokrotnyi, mokryi and adverbs mokro, mokrenno) and vlaga (1988: 359, 112). It is notable that the translator suggested several possible equivalents. Since scientific language prefers terms with (ideally) one fixed meaning, rather than several synonyms, Polykarpov seems to have seen his main function as being to offer to the target system 'candidates' for equivalents, while leaving the final selection to his readers or, in social-systemic terms, to the system.

Polikarpov's goal in compiling the dictionary was to educate younger generations (1704: 4: “... юнош учащихся вразумление умножится и преуспеет", "[so that] the understanding of the youth might multiply and thrive"). This purpose explains why Polikarpov made sure that his entries were clear to the Russian reader and in general preferred Russian indigenous words: $A$ is rendered as $B$, where $A$ is an element of the source system and $B$ is an element of the target system. Even if he transliterated a foreign term, he usually supplied a Russian synonym, as in the case of the word aer (air): "Aер, воздух..." (Polikarpov 1988: 18). In the entry 'vozdukh' [air], however, he did not provide 'aer'; in fact, he seems to have considered the latter unnecessary, since 'vozdukh' was clear enough to any Russian reader.

This, however, was not always Polikarpov's translation strategy outside his dictionary. In a later translation, Polikarpov's 1718 version (Geografiia general'naia) of the book Geographia generalis (1650) by Bernard Varenius, the following sentence is found: “Да будет ликвор или мокротность некая состоящая EJGH, центр земли D и возмним мокротность оную пресекатися планом, преходящим через D" (literally: "Let a certain liquid or wetness be constituted EJGH, the centre of the earth D, and let us imagine the wetness to be crossed by a plane passing through D" (cited in Kutina 1966: 113; in the original: "...sit liquor aliquis consistens EFGH, centrum terrae $\mathrm{D}, \&$ concipiamus liquorem istum secari plano transeunte per D" (Varenius 1650: 134). Here, the word liquor is used twice; the translator transliterated the first liquor but added a Russian equivalent: “...ликвор или мокротность...”. In the second instance, the word (...liquorem...) is rendered using the Russian term alone (“мокротность”). As was the case with his trilingual dictionary, the reason for his preference for the Russian word here is clear if we consider the following. According to his introduction to Geografiia general'naia, his rationale was to introduce Latin or Greek terms "for the better knowledge of the subject" ("ради 
лучшего в деле знания"), yet to pair them up with Russian equivalents "to help students understand them" ("ради лучшего учащимся вразумления") (cited in Nakoriakova 2004: 72). The translation, thus, linked the Russian text with its original, yet it also attempted to find a corresponding word in the target language. The translator introduced the reader to the common European pool of knowledge, and it appears that the original Latin terminology was needed for that, yet the Russian equivalent was deemed necessary to ensure the reader's full understanding. A sort of 'buffer zone' was created. The translation here bridged the gap between the source and the target by including both the source and target elements - not by replacing the former with the latter: $A$ is translated not by $B$, but by the group ' $A_{1}$ or $B$ ', where $A_{1}$ is a transliteration of $A$. This type of translation suggested two different ways of rendering a scientific notion and contributed to the set of potential Russian terms.

The case of liquor $\Rightarrow л и к в о р$ illustrates the Latin $\Rightarrow$ Vernacular direction of translation. The Russian transliteration ликвор (likvor) as a rendering of the Latin liquor was also suggested by Antiokh Kantemir in his 1730 version of Bernard de Fontenelle's Entretiens sur la Pluralité des Mondes (Conversations on the Plurality of Worlds, 1686). Kantemir rendered the French liqueur as the Russian ликвор; yet he explained the word in a short dictionary, appended to his translation, as an originally Latin term "which means any substance, whose parts are not hard, but fluid, such as water, wine, beer etc." (Kantemir 1868: 423). The translator rendered the French word but traced it back to its Latin original: $\mathrm{L} \Rightarrow \mathrm{V}$ (French) $\Rightarrow \mathrm{V}$ (Russian).

Kantemir's translation, in contrast to the previously discussed translation by Polikarpov, did not suggest any Russian equivalent for the original Latin term, not even in the explanatory entry in his Dictionary. Note that in his introduction Kantemir justified the inclusion of the Dictionary, because sometimes he "was forced" to use foreign words when he could not find Russian equivalents (“которые и не хотя принужден был употребить, своих равносильных не имея,” 1868: 391). Kantemir chose to introduce new words into the Russian language and explain them, rather than provide "unequal" Russian words: $A$ was rendered as $A_{l}$. This type of translation does not create any buffer zone; rather, it suggests a way of entering the European subsystem of science by appropriating the latter's own medium of communication with its terminological apparatus.

Flegma is another word used in eighteenthcentury Russian translations of the word liquid. It was a Greek term flegma that had been appropriated into scholarly Latin; it first appeared in Russian in translations of German scientific texts. In Russian the term usually meant water. This term provides us with an example of yet another type of borrowing: $\mathrm{G} \Rightarrow \mathrm{L} \Rightarrow \mathrm{V}$ (German) $\Rightarrow \mathrm{V}$ (Russian). The term is rendered into Russian by means of transliteration: $A \Rightarrow A_{1}$, as in the case of liquor $\Rightarrow л и к в о р$. Incidentally, this is also how the term flegma was rendered by Polikarpov (1988: 724). He supplied the noun flegma with the adjective flegmatichnyi and the noun flegmatik (phlegmatic).

The term vlazhnost' became the success story in Russian scientific terminology as a translation of the term humidity, while zhidkost' was used equally successfully for the term liquid. Vlazhnost' had been accepted as a term by the 1730s and is still used today as the Russian term for humidity (Kutina 1966: 161). It appeared in translations from German and seems to be a morphological calque of the German Feuchtigkeit. The Russian term followed the German word-formation pattern: an abstract nominal suffix was added to the adjectival stem in Russian as it was in German: Feuchtigkeit = 
feugt(ig)+keit $\Rightarrow$ влажн(ый)+oсть = влажность (Sorokin 1987: 199). The direction of translation was, thus, from a vernacular into a vernacular $\mathrm{V}($ German $) \Rightarrow \mathrm{V}$ (Russian).

The term zhidkost' (liquid) gained the status of a physical term in the mid-eighteenth century (Kutina 1966: 162). It was already appearing in early eighteenth-century translations from German - e.g., those made in 1708 and 1738 (Kutina 1966: 161; Sorokin 1987: 132). The translation pattern once again followed the German prototype: жид/тк(ий)+ость $=$ жид/ кость.

These two translations are different from those discussed above. This type of translation is a fusion of the elements of the interacting linguistic systems. Morphologically it is a calque, and therefore could be presented as $A \Rightarrow A_{1}$. Yet on the lexical level, we see the $A \Rightarrow B$ pattern, because Russian morphemes were used.

In the two latter cases, the calqued variants, suggested by translation, ousted all the other variants. With other scientific terms, the variants $A_{1}$ or $B$, as the results of $A \Rightarrow A_{1}$ or $A \Rightarrow B$ respectively, were more successful. The above adduced words flegmatichnyi and vozdukh (vs. aer, air, see Sorokin 1984: 29, 32), which are used as terms in psychology (flegmatichnyi) and in physics and other sciences (vozdukh), furnish examples of the $A \Rightarrow A_{1}$ or $A \Rightarrow B$ patterns respectively.

Clearly, variants of the type ' $A_{1}$ or $B$ ' could never 'win', because in the scientific terminological system used in vernaculars the tendency was to select only one term per notion. The groups ' $A_{1}$ or $B$ ' turn out to be unstable: one of the two (or more) suggested variants must be legitimised as a term, while the rest are rejected as part of the target system's scientific terminology. But variants of the type ' $A_{1}$ or $B$ ' were (and still are) a frequent option in scientific translation at the stage of introducing new terminology. (In Luhmannian terms, the ' $A_{l}$ or $B$ ' strategy allows translation to perform its meaning-creating function, which I have discussed elsewhere (Tyulenev 2009b).)

There was one factor which had an influence over which terminological options a translation could suggest. The dictionaries, such as Polikarpov (1988) and Weismanns (1982), were translated dictionaries (the translators-compilers of Weismanns (1982) were I. Safarov, I. Il'inskii, I. Gorlitskii and the general editor V. Adadurov). The authors of the Russian dictionaries were translators rather than compilers: they borrowed the vocabulary of their source dictionaries, to which they then added Russian translations. This explains why Weismanns (1982), which was translated from German, had no entries which would have suggested the translations flegma or likvor, since these were the Greek and Latin terms and were not used in the German dictionary. It is also unsurprising that Polikarpov (1988), which prioritised Greek over Latin as the source of its entries, has flegma (724), but not likvor. Likvor is found in translations from Romance sources (Latin/French), as in Polikarpov's version of Geographia generalis by Varenius, or in Kantemir's version of Fontenelle's Entretiens... Thus, the suggestive capacity of a translation was determined by its source.

To conclude this section, in the case of the proto-terminological series of liquid/humidity, (1) translation played an active role in suggesting potential terms, some of which were selected and legitimised by the target system; (2) translation produced variants by suggesting either a transliteration of the term used in the original, or its morphological calque, or its possible Russian equivalents. In the latter case, Kantemir pointed to the possibility of modifying the meaning of the Russian word (“для русских, употребленных в ином разумении, нежели обыкновенно чинится," 1868: 391). Translation formed a sort of buffer zone, including both renditions that were closer to the source languages and those that 
were closer to the target language, according to the scheme ' $A_{1}$ or $B$ '. The following tendency is observed.

The Latin or Greek terms (liquor $\Rightarrow$ ликвор; flegma $\Rightarrow$ флегма) seem for the most part to have been straightforward transliterations, while borrowings from vernaculars were calqued or provided with Russian equivalents (Feuchtigkeit $\Rightarrow$ влажность). However, it will be necessary to obtain more data in order to substantiate this observation.

\section{Transfers}

...для сочинения социетета наук, подобно как в Париже, Лондоне, Берлине и прочих местах... [...in order to create a society of sciencies such as those in Paris, London, Berlin and other places...]

-Peter the Great

(cited in Pekarskii 1862: vol. I, p. 534)

Although language is by far the most powerful means of social-systemic communication (Luhmann 1997: 47; Baraldi, Corsi, Esposito 1997: 180-3), one should not limit transfers to verbal translations alone. The entire scientific system in Russia was by and large the result of transferring contemporary Western European models, as is clearly stated in the following principle set out in the Charter of the Academy: “...more aliarum in Europa Academiarum" (in the fashion of European Academia; Novi 1750: $15)$.

Although the concept of the first university was suggested in the seventeenth century by Semen Medvedev (1641-1691), alias Sil'vestr, his church name (Bogdanov 1990: 20), the project was only properly developed and finally realised as part of the Westernisation of Russia under Peter in the eighteenth century. On January 20, 1724, Peter issued an order for the Senate to prepare a decree establishing the Russian
Academy "where languages would be taught as well as other sciences and arts and where books would be translated" (my translation from the facsimile reproduction in Osipov 1999: 185). On January 28, 1724, the decree was duly issued and published. The Academy was supposed to have a university; the former was to be the institution where scientists would conduct their research, whereas the latter was to become the place where students would be taught. Later, a school, preparing younger students for entering the university, was also set up.

The lectures at the university were to be given in either Latin or Russian, but in the Charter a perfect command of Latin was stipulated as a requirement for university students: “...students should already be skilful in the Latin language so that they can understand lectures in sciences, which should be given in no other languages but Latin and Russian" (Novi 1750: 27-8). Yet although the scientific discourse had to be in Latin and Russian, other languages were not to be neglected. The Charter of the Academy states:

[Article] 38. The University should be modelled on other European Universities... Latin, Greek, French and German should be taught in special courses. Pupils on these courses shall become students who will attend lectures in Latin or Russian. (Novi 1750: 28)

In this Article, the hierarchy of languages is clearly established: lecturing/studying was to be in Latin or in Russian, yet students had to know Greek, French and German. At the University of Moscow founded in 1755, virtually the same scheme was adopted. Before being accepted, students were examined in mathematics, linguistics and Latin (Iushkevich 1948: 45). Once again, although Latin was mandatory, Russian, German and French were also taught. 
It was emphasised that the University, as part of the Academy, was to be modelled on European universities:

At the beginning of each year, academics should offer a problem which the President... will publish for the general public, and whoever solves the problem should be rewarded. This is to be done in the fashion of other Academies. (Novi 1750: 22, see also pp. 19 [Article 11], 30 [Article 44], 32 [Article 47].)

\subsection{Leibniz's Advice}

A certain nobleman wanted to build a mill on his estate, but had no water. Seeing his neighbours' lakes and marshes with plenty of water, he asked them to permit him to use their water. When they agreed, he immediately set out to dig aqueducts to his mill, which he, however, could not complete, yet his children, moved by their father's diligence, had to continue his labour and they finished it.

-Peter the Great

(cited in Pekarskii 1870: vol. 1, p. XIII)

The influence of Western European models can be further exemplified by Peter the Great's correspondence with Leibniz, who became a major advisor on how the Saint-Petersburg Academy should be organised.

Their first meeting took place in 1711 when Peter, while staying in Torgau (Germany), granted Leibniz the title of his advisor. Among his numerous pieces of advice, Leibniz emphasised the importance of promoting sciences and arts in Russia. He suggested that the majority of scientists should live in Russia, but that some of them should remain abroad in order to report on what was worth knowing to the Russia-based academics (Pekarskii 1862: vol. 1, p. 26). Petr Pekarskii, on whose detailed account of the correspondence between Peter and Leibniz I draw here, uses the Russian equivalent of the verb 'remain', which suggests, if Pekarskii is conveying Leibniz's own expression, that the first scientists were to be foreigners. The implication is that some of the scientists would be invited to settle in Russia, whereas others would remain abroad. This logic is further corroborated by Article 36 from the Charter of the Academy: "Russia cannot afford to have only learned people who already work in sciences, but younger generations should also be raised. In future, they will replace the present-day academics. This goal is all the more important, given that initially the Academy could not have been staffed but by foreigners. Ultimately, however, the Academy should be composed of native Russians, for which purpose another part of the Academy shall be set up, the university" (Novi 1750: 27). Indeed, according to the Charter of the Saint-Petersburg Academy (1750), there were to be ten academics in Russia and one in each of the major European countries so that the Academy would be informed about "all places in Europe" (Novi 1750: 17).

Leibniz also offered his advice on how to avoid the mistakes and abuses (zloupotrebleniia) "of which educational institutions in the West were full" (Pekarskii 1862: vol. 1, p. 27). For example, Saint-Petersburg Academy had its own university in order to speed up the preparation of 'native' Russian scientists and scholars. In this respect, the Saint-Petersburg Academy differed from the Academy of Paris (Pekarskii 1870: vol. 1, p. XXX). In the archives of the Academy of Sciences, Pekarskii found a translation of an account of Leibniz' projects involving the establishment of a university (for teaching) and a Gelehrt-collegium, a scientific society proper (1870: vol. 1, pp. XXI-II).

In another letter, Leibniz suggested setting up nine governmental departments, dealing with home (state) and military affairs, with finances, 
law, trade, religions, audit and sciences. Peter's decree of December 12, 1718, on establishing governmental departments also lists nine departments, although slightly different. Leibniz offered advice on all departments except the departments of home and military affairs. He focused, however, on the department of sciences. In the following table, I will compare some of Lebniz's suggestions with passages from the Charter of the Academy published in 1750 which seem to echo Leibniz's advice (the pagination in the left-hand column is according to Pekarskii 1862: vol. 1; that in the right-hand column is according to Novi 1750 , and the numbers and emphases are mine throughout - S.T.): that Leibniz's advice was followed to a T; rather, I have tried to demonstrate some of the transfers he suggested for the establishment of Russian science.

The role of Leibniz was so remarkable that both in Russia and abroad it was believed that "our Academy of sciences was established by the Emperor based on Leibniz's ideas and suggestions" (Pekarskii 1870: vol. 1, p. XXII). Indeed, the prophecy of Peter the Great, quoted in the epigraph to this section, was fulfilled: although what he planned with his "neighbours", such as Leibniz, was not finished during his lifetime, his "children" completed it.
Scientists should be selected from among those who are (1) well established in sciences-not halfignoramuses, of whom there will be none (2) of benefit to the state (p. 28). (1)...nobody shall be elected as an academic or an adjunct unless he has demonstrated his science to the scientific community (p. 20; cf. also p. 33 [Article 50]).

(2) The state will have neither benefit nor glory unless there be people in it who know the courses of celestial bodies and their seasons, seafaring business, the geography of the entire world and of their own state... (pp. 14-15, also Articles 3, 4, 7, 16 and passim.)

Scientists should teach according to (3) up-to-date methodologies and watch for new discoveries and improvements that are made in their field of research (p. 28).

(4) Younger generations should be taught all sciences. An institution of higher education should be established for teaching young people (p. 28). society might face (p. 28).

The Academy and its subordinate educational institutions should have their own (6) resource base, including buildings, gardens, libraries, laboratories etc. (pp. 26-8).
(3) Each academic should read new authors in his science, report about new developments and recommend the best of new works for translation and publication (p. 23).

(4) Several articles in the Charter stress the importance of educating younger generations and ensure mechanisms of passing knowledge from academics, professors and teachers to adjuncts, students and pupils (Articles 9, 36-44, 47-8).

(5) Article 35 stipulates the possibility of inviting a scientist to any of the governmental departments for a consultation or advice (pp. 26-7).

(6) Articles 50-8 discuss the Academy's ancillary services and institutions, also a library, a press etc.
Undoubtedly, other similarities between Leibniz's suggestions and the principles which informed the creation of the Saint-Petersburg Academy could be found. My contention is not
There were other Western European advisors. The correspondence of Peter the Great, through his doctor Areskin, with foreign scientists started not later than 1715. In 1717, during his visit to Paris, 
Peter personally met a number of French scholars and later exchanged letters with them, once again through Areskin. On one occasion Peter's librarian, Schumakher, was sent to Europe to make connections with European scholars. Later, the closer the opening of the Academy drew, the more active Peter's correspondence with foreign scholars and scientists grew. He invited some of them to visit the Saint-Petersburg Academy, once it had been established, and observe its operation (Pekarskii 1870: vol. 1, p. IV). Apparently, there were other foreign advisors, some of whose names are lost (ibid.: XX-I, XXV-VI).

\subsection{A Russian Encyclopaedist}

Vasilii Tatishchev (1686-1750) is known as the father of the modern Russian historiography, yet he was also one of the first Russian polymaths. He provides an example of another type of transfer of Western European knowledge onto Russian soil.

A third of the books in Tatishchev's personal library were in foreign languages, mainly German, but also in French, Polish and Latin. These were encyclopaedias, historical and geographical dictionaries, translations of classical writers and scientific publications. His collection was similar to the personal collections of his contemporaries, such as Prokopovich, Brius, Golitsyn, Matveev and Volynskii, among others. Yet Tatishchev's is a more encyclopaedic library than those of his contemporaries. Russian scholars such as Prokopovich and Kantemir drew more on what may be called primary sources, such as scientific treatises or books, rather than digests summarising important theories and discoveries. For instance, Prokopovich's principal political treatise, Pravda voli monarshei (Justification of Monarchy), is based on several theories borrowed from original works on natural law (notably, Grotius). Kantemir wrote in the notes to his satires and odes that he was greatly indebted to the classics, such as Horace and Cicero, and scientists whom he translated, Fontenelle and Newton.

Tatishchev drew mainly on Western European 'secondary' sources. This, however, allowed him to encompass a wider range of materials. Whereas Prokopovich's and Kantemir's contribution to the nascent Russian scholarship was limited to a handful of fields, Tatishchev appropriated Western culture in a dozen different areas, among which were geology, geography, ethnology, linguistics, history, law, politics etc.

Tatishchev familiarised himself with the first encyclopaedias produced in the West - those by Bayle (1697), Huebner (1716) and Walch (1726). Tatishchev did not necessarily translate from them but his scientific and scholarly output was imbued by those encyclopaedists' principles and the knowledge they popularised. His works reflected the Western understanding of what an intellectual should know. Following the common contemporary Western European practice, Tatishchev borrowed profusely from those encyclopaedias. In his Dialogue Between Two Friends on the Usefulness of the Sciences and of Schools (1733), he adopted, sometimes translating, sometimes retelling his sources, entire paragraphs on the nature of soul, humankind, education, law, the division of the sciences, knowledge, reason and a number of other topics from J. Walch's Philosophisches Lexicon (Leventer 1972: 153, 228-31).

The idea to read Walch was probably suggested to Tatishchev by the first academics of the Russian Academy of Sciences, most of whom were Germans (Leventer 1972: 232). Tatishchev espoused Walch's ideas as reflected in the latter's encyclopaedia. He was sympathetic to Walch's philosophy with its ideas of natural law, scepticism and scientific rationalism. Yet he did not borrow from Walch blindly. He relied on Walch only in domains little known to him, such as philosophy and political theory, but he would 
challenge Walch's opinions when he had his own. For instance, Walch believed that a country's wealth consisted of the gold and silver it possessed. Tatishchev, on the other hand, was a mercantilist. He supervised the work of Russian mines and factories, and therefore he knew about other forms of wealth. In such instances, Tatishchev would abide by his personal convictions. Yet again, he developed his ideas against the background of other Western economic theories: he dismissed Walch in favour of Western European mercantilist ideas.

Tatishchev also learned a great deal from Christopher Polhem (1660-1751), the father of Swedish technology and an ardent enlightener. Polhem believed in the evolutionary development of the world. Tatishchev adopted some of his argumentation: for instance, the contention that God could not have created everything because there are numerous useless things in the world, such as mountains, marshes and swamps, which "obviously came about because of changes of the earth's surface" (Polhem as cited in Leventer 1972: 167). Polhem also asked the question: How could God have separated day from night before he created the sun and the moon? Tatishchev expressed similar ideas in his scientific output. Polhem's interest in the practical science of collecting data without excessive theorisation was also echoed in Tatishchev's own writings.

Another Swedish friend of Tatishchev who greatly influenced him was Eric Benzelius (16751743). They corresponded from 1726 to 1743 . Thanks to Benzelius, Tatishchev was exposed to the most advanced trends of the scientific thought in Europe. It is believed that Benzelius's historical interests and ideas made their way into Tatishchev's history of Russia (Leventer 1972: 169-71).

Tatishchev travelled to Sweden at a time when that nation was making great advances in sciences. Swedish scientists kept close contacts with the most prominent scientists in England. In the mid-1720s, Jonas Alströmer (1685-1761) brought from England the knowledge of new agricultural products (potatoes and tobacco) and of the recent breakthroughs in animal husbandry. He introduced this know-how on his farms. In 1728, Mårten Triewald (1691-1747) brought the first steam engine from England. Polhem and Benzelius, among others, suggested modelling Swedish social institutions on English ones. In 1710, a group of like-minded innovators, a number of whom corresponded with members of the British Royal Society, started a group called Collegium Curiosorum at Uppsala. A decade later, they became the Scientific Society with its scholarly journal. By the end of the 1720s, they had a charter as the royal Societas Literaria et Scientiarium.

All these developments did not fail to instil in Tatishchev the same admiration for the British Royal Society's version of Baconian science. Incidentally, there were direct links between London and Saint-Petersburg. The Society's secretary, Hans Sloane (1660-1753), was in contact with Russian academics, among whom was his former student Johann Amman (1707-41). Amman joined the Academy in 1733. Sloane's intention was to use Russia as a source for the Royal Society's Philosophical Transactions. Sloane wanted to make the latter an international scientific journal, a place of scholarly exchange. Tatishchev kept a close eye on the work of the Royal Society through the Saint-Petersburg Academy's journals, which regularly published translations and summaries of scientific works by their English colleagues.

Tatishchev became a Baconian, in that he believed that in order for valid conclusions to be drawn and generalisations made, all available and relevant data had to be painstakingly collected. The first stage was compared by Bacon in his Novum Organum (1620) to the labour of ants; the 
second, to that of bees. He compared groundless speculations to spiders spinning their webs out of their own substance. Tatishchev practised Baconianism with its somewhat over-emphasised ant-like collecting of data and putting off of generalisations to the future. Tatishchev's first scholarly work, a paper on mammoth tusks found in the Urals, was written under the influence of Benzelius and set the tenor for his future scholarly work within the Baconian philosophy of science.

In 1725, Tatishchev published his article on the 1720 discovery of mammoth tusks and bones as well as large underground caves in the Urals. Noteworthy is the fact that Tatishchev published his paper in Sweden. In his article, Tatishchev developed his argumentation about the provenance of the remains against the background of the hypotheses elaborated by John Woodward (1665-1728), who believed the tusks were the remains of Indian elephants carried all the way from India to Siberia by the Deluge. Tatishchev rejected the theory of the German Philipp Cluever (1580-1622), according to which Siberia had been the elephants' natural habitat before the earth's axis shifted. Tatishchev's article aroused interest and was used by Hans Sloane, the Secretary of the Royal Society in London, as the basis for his summary of all hypotheses about the tusks (1729).

According to Herbert Leventer, Tatishchev's critical assessment of the existing explanations of the tusks' origin must have been a result of his trip to Sweden (1972: 179). Samples of the Siberian tusks in the form of snuff boxes and other trinkets were brought to Sweden by Swedish prisoners of the Great Northern War (1700-21), who had been sent to Siberia after Peter's victory over Sweden. The samples aroused curiosity among the Swedish elite who, in turn, asked Tatishchev to explain them. Tatishchev probably wrote his paper in order to address such inquiries. Tatishchev's criticism of faulty theories, however, was not only nurtured by the Swedish, but also, through them, was spurred on by the English.

The story of Tatishchev's article on mammoth tusks had a continuation, which further exemplifies how scientific theories travel through transfer. Tatishchev's article was published in the scientific journal of the Saint-Petersburg Academy of Sciences in a Russian translation. Thirty years later, based on Tatishchev's argumentation, Mikhail Lomonosov proved his own theory that the face of the earth changed continuously. Lomonosov also drew on Cluever's theory of the shift in the earth's axis for his explanation of the climatic change that had taken place in Siberia. Furthermore, Lomonosov's theory regarding organic change in the earth's crust led him to conclude that black soil (chernozem) is formed from the remains of plant life. This idea was taken up by another Russian scientist - Vasilii Dokuchaev (1846-1903) - in his book entitled Russkii chernozem (Russian Black Soil, 1883) (Morozov 1961: 423). The chain of transfers in this particular case linked England, Germany, Sweden and Russia and passed from Tatishchev through Lomonosov to Dokuchaev.

Thus, Tatishchev saw himself as a member of the international community of scholars. He adoptedandadapted WesternEuropeanknowledge and saw his discoveries as contributions to the international scientific community.

\section{European Global Science System}

The example of Tatishchev is by no means an exception. A multitude of other facts demonstrate Russian scientists' aspiration to be integrated into the Western European science system. In the few examples which follow, I would like to show how the complex network of the transfers that took place during the Westernisation of Russia were incorporated into the globalisation of the European science function system outlined earlier: (1) Russia's borrowing from Europe; 
(2) its projecting information about itself into Europe, and (3) its endeavour to become part of the European global function system (Luhmann 1990: 178).

Iakov Brius (1669-1735), a close associate of Peter the Great and a prominent state official, was also a scientist and corresponded not only with foreign politicians but also with scholars, some of whom were of the highest international renown, notably Leonhard Euler (Rybkin and Iushkevich 1957). The mutual benefit of such exchange of ideas can be demonstrated with the help of Brius's correspondence with Johann-Georg Leitmann (1667-1736) about physics. Leitmann was invited (thanks to Brius's recommendation) to the Saint-Petersburg Academy, although Brius had contacted Leitmann earlier. The first surviving letter is dated 1726. Their correspondence testifies to an active exchange of ideas, instruments, books and manuscripts of their works. One of Brius's successful optical experiments was made known to the "scientific world" by Leitmann (Koshtoianz 1951: 1088).

The correspondence was written in German with occasional Latin terminology, e.g., vitro plano convexo et altero utrinde plan, Speculi Newtoniani, specula (ibid.: 1099-100, 1101). Although there is no verbal translation here, this example shows how Russian science entered Western European science: a Russian cooperated with a German, German and Latin being the means of communication.

Some of Brius's ideas travelled westwards [Aspect (2)], some in the opposite direction [Aspect (1)]; as a result, the exchange contributed to the globalisation of the European science function system [Aspect (3)].

Scientific ideas were not always transferred in such a noble and mutually respectful manner, however. The Russian autodidact Ivan Kulibin (1735-1818) invented, among many other things, artificial legs (prostheses). This invention was prompted by the aftermath of the wars in Catherinian Russia in the late eighteenth century. Kulibin conducted the first experiments in the early 1790s. Yet the red tape made the implementation of the prosthetic device on a mass scale in the Russian Empire problematic. Another attempt to offer his invention to the officials was made by Kulibin in 1808 during the Napoleonic Wars in which Russia participated. Once again his effort proved futile. But some Frenchman learned about his invention and showed it to Napoleon who ordered that it be mass-produced for his soldiers, and the pseudo-inventor profited immensely (Koshtoianz 1948: 69). This is also an example of a transfer, yet it was a transfer which today would be qualified as military and industrial espionage and theft. In this case, the transfer was directed westwards, out of the system into the system's environment, to use Luhmannian terms [Aspect (2)].

In his list of scientific works (1763), Lomonosov wrote about his mosaics which he considered to be improvements of the "Roman (Italian) mosaics" (Koshtoianz 1948: 17). Lomonosov compared his mosaics with the Italian ones because he had borrowed the idea after having seen the mosaics which had been brought to Russia from Italy by Count Mikhail Vorontsov in the mid-1740s. Lomonosov developed the technique and later was selected to be a member of several Italian scienitific societies for this work. This was a transfer from the environment into the system [Aspect (1)].

It is important to broaden the concept of translation to include this kind of transfer, because otherwise our understanding of the function of translation in such regions and in such historical periods as eighteenth-century Russia would be severely limited, if not distorted. For example, the translation into Russian of Comte de Buffon's magnum opus Histoire naturelle was undertaken until 1789, yet Buffon's ideas had 
started to trickle into Russian scientific oeuvres significantly earlier. The first volume of the work in France appeared in print in 1749. Apparently, the first three volumes came to the attention of Russian scientists soon after their publication. Lomonosov knew about them and Buffon's ideas influenced Lomonosov's geological theories, notably his treatise on the strata of the earth (1763). Peter Simon Pallas (1741-1811), a German-Russian academic, cited Buffon in a work published in 1777. Another channel through which Buffon's ideas penetrated into Russia was a treatise published by the Russian student Afanasii Kaverznev (1748-?) in 1775. Kaverznev studied at the University of Leipzig. Kaverznev shared Buffon's ideas and significantly developed as well as openly discussed what Buffon had only implied, for example that all animals evolved from one ancestor. Kaverznev's treatise was published in Russia by the publisher Nikolai Novikov in 1778 and 1787 in a translation made by a certain I. Morozov. Novikov also published translations of books about Buffon and his theory. During the same period, in journals, fragmentary and anonymous translations of Buffon's writings were published from time to time. In 1757, a critical article entitled "Corrections of the Errors Made by $\mathrm{Mr}$ de Buffon in the first part of his Natural History in His Descriptions of Different Regions and Places of the Russian State" was released. Some mistakes were real; some were imagined. In 1759, a translation of Buffon's 1738 article on forestry was published. In 1786, Buffon's speech on style was published. In the 1790s and early 1800 s, articles about Buffon appeared in several journals.

Yet the first translation of Buffon's Histoire naturelle was not initiated until 1789, by Catherine the Great. The Empress contacted Buffon through Friedrich von Grimm. Buffon sent her his works. Catherine commissioned a translation to be carried out by the Academy of Sciences. Several academics, Lepekhin, Rumovskii, Inokhodtsev, Ozeretskovskii, Zuev, Kotel'nikov, Protasov and Sokolov, started the work. In 1795, for political reasons during the time of the French revolution, the translation was suspended and was later finished by Lepekhin alone (Kanaev 2000: 12030).

If we limit translation to its verbal aspect alone, then we would be ignoring the transfers of Buffon's ideas which had occurred before his texts were rendered into Russian, and we would thus be unable to account for the complexity of the transfers in this case.

\section{Conclusion}

In the present article, Ihave considered several aspects of the role of translation in the spread of scientific ideas as part of the Westernisation of Russia. The Westernisation of eighteenth-century Russia consisted of three aspects: (1) Russia's borrowing from Europe; (2) Russia's making contributions to European science, and (3) the efforts of Russian scientists to integrate Russian science into the European global science function system. In this article, special attention has been given to the third aspect.

Translation normally functions as a boundary phenomenon of a social system. Yet in the globalised system of eighteenth-century Europe, the role of translation became more complex. In the global science system, translation was involved in resolving the paradox of the Enlightenement agenda, which had the dual, and seemingly conflicting, aim of pursuing scientific research as an international endeavour while at the same time making knowledge universally accessible within a given society in its own language. No ideal solution was found, as is obvious from the language policy of the Saint-Petersburg Academy of Sciences in its early publications. There is, however, no doubt that translation played a vital role in ensuring 
communication among the enthusiasts of science, both academic staff and the general public, speaking different languages yet sharing the same interest in sciences. The Academy's reports were published in Latin accompanied by Russian, French or German translations, or they were published in one vernacular and translated into another.

Mutatis mutandis, the same situation is observed in the strategies of translating terminology. Sometimes translators preferred transliterations, sometimes they opted for calques, and sometimes they tried to find
Russian equivalents. But all the time, they looked for a way to negotiate between the national universalism of science and its internationalism.

In the final part I emphasised the importance of broadening the concept of translation to include other types of transfer. This is necessary in order to understand, in a more comprehensive way, the nature of social processes like the Westernisation of eighteenth-century Russia, when social systems actively interact with their environment by giving and taking across their boundaries.

\section{References}

1. Acta 1780: Acta Academiae Scientiarum Imperialis Petropolitanae. Pro Anno MDCCLXXVIII. Pars Prior. Petropoli: Typis Academiae scientiarum. MDCCLXXX.

2. Acta 1781: Acta Academiae Scientiarum Imperialis Petropolitanae. Pro Anno MDCCLXXVIII. Pars Posterior. [MDCCLXXVIII. Juillet-Décembre]. Petropoli: Typis Academiae Scientiarum. MDCCLXXXI.

3. Baraldi, von Claudio, Giancarlo Corsi und Elena Esposito (1997) Glossar zu Niklas Luhmanns Theorie sozialer Systeme. Frankfurt am Main: Suhrkamp.

4. Birzhakova, Elena, Lidiia Voinova, and Lidiia Kutina (1972) Ocherki po istorii leksikologii russkogo iazyka XVIII veka [Essays on the History of Lexicology of Eighteenth Century Russian]. Leningrad: Nauka.

5. Bogdanov, A.P. (ed.) (1990) Rossiia pri Tsarevne Sof'e i Petre I [Russia under Tsarina Sof'ia and Peter the Great]. Moscow: Sovremennik.

6. Commentarii 1728: Commentarii Academiae Scientiarum Imperialis Petropolitanae. Tomus I. Ad annum 1728. Petropoli: Typis Academiae.

7. Huettl-Worth, Gerta (1956) Die Bereicherung des russischen Wortschatzes im XVIII. Jahrhundert. Wien: Verlag Adolf Hozhausens Nfg.

8. Iushkevich A.P. (1948) "Matematika v Moskovskom Universkitete za pervye sto let ego sushchestvovaniia" [Mathematics at the University of Moscow during the First One Hundred Years of Its Existence] in Rybkin G.F. and A.P. Iushkevich (eds) (1948) Istoriko-matematicheskie issledovaniia [Historical and Mathematical Investigations]. Vypusk I [Issue 1]. Moscow: Gosudarstvennoe izdatel'stvo tekhniko-teoreticheskoi literatury. Pp. 43-140.

9. Kanaev, Ivan (2000) Izbrannye trudy po istorii nauki [Selected Works on the History of Science]. Saint-Petersburg: Aleteiia.

10. Kantemir, Antiokh (1868) Sochineniia, pis'ma i izbrannye perevody [Works, Letters and Selected Translations]. Vol. 2. Saint-Petersburg: Tipografiia Glazunova.

11. Koshtoianz, Khachatur (ed) (1948) Nauchnoe nasledie [Scientific Heritage]. Vol. 1. MoscowLeningrad: Akademiia Nauk SSSR. 
12. Koshtoianz, Khachatur (ed) (1951) Nauchnoe nasledie [Scientific Heritage]. Vol. 2. Moscow: Akademiia Nauk SSSR.

13. Kutina, Lidiia (1966) Formirovanie terminologii fiziki v Rossii. Period predlomonosovskii: pervaia tret' XVIII veka [Formation of Terminology of Physics in Russia: Early Eighteenth Century]. Moscow, Leningrad: Nauka.

14. Leventer, Herbert Michael (1972) Tatishchev: Science and Service in Eighteenth Century Russia. Manuscript of the Ph.D. thesis. Columbia University. Ann Arbor: Xerox University Microfilms.

15. Luhmann, Niklas (1990) Essays on Self-Reference, New York: Columbia University Press.

16. Luhmann, Niklas (1997) Die Gesellschaft der Gesellschaft. Frankfurt am Main: Suhrkamp.

17. Lukina, Tat'iana (1965) Ivan Ivanovich Lepekhin. Moscow-Leningrad: Nauka.

18. Luppov, Sergei (1976), Kniga v Rossii v poslepetrovskoe vremia [Books in Post-Petrine Russia], Leningrad: Nauka.

19. Morozov, Aleksandr (1961). Lomonosov. Moscow: Molodaia Gvardiia.

20. Nakoriakova, Kseniia (2004) Ocherki po istorii redaktirovaniia v Rossii v XVI-XIXvv. [Essays on the History of Editing in Russia in the Sixteenth-Nineteenth Centuries]. Moscow: VK.

21. Novi 1750: Novi Commentarii Academiae Scientiarum Imperialis Petropolitanae. (1750) Tom 1 ad Annum MDCCSLVII et MDCCXLVIII. Petropoli: Typis Acadmiae Scientiarum.

22. Osipov, Yurii (1999) Akademy of Sciences in the History of the Russian State. Moscow: Nauka.

23. Pekarskii, Petr (1862) Nauka i literature v Rossii pri Petre Velikom [Sciences and Literature in Russia under Peter the Great]. Saint-Petersburg: Obshchestvennaia pol'za.

24. Pekarskii, Petr (1870) Istoriia imperatorskoi Akademii naukv Peterburge [A History of the Petersburg Imperial Academy of Sciences], Sankt-Peterburg: Tipographiia Imperatorskoi AN.

25. Polikarpov, Fedor (1988 [1704]) Leksikon trejazycnyj. Dictionarium trilingue. Muenchen: Verlag Otto Sagner.

26. Rybkin G.F. and A.P. Iushkevich (eds) (1957) Istoriko-matematicheskie issledovaniia [Historical and Mathematical Investigations]. Vypusk X [Issue 10]. Moscow: Gosudarstvennoe izdatel'stvo tekhniko-teoreticheskoi literatury.

27. Smith, May (2007) The Influence of French on Eighteenth-Century Literary Russian: Semantic and Phraseological Calques, Oxford: Peter Lang.

28. Sorokin, Iu. S. (ed) (1984) Slovar' russkogo iazyka XVIII veka. Vypusk 1 [Dictionary of Eighteenth Century Russian. Vol. 1]. Leningrad: Nauka.

29. Sorokin, Iu. S. (ed) (1987) Slovar' russkogo iazyka XVIII veka. Vypusk 3 [Dictionary of Eighteenth Century Russian. Vol. 3]. Leningrad: Nauka.

30. Tyulenev, Sergey. (2012a). Applying Luhmann to Translation Studies: Translation in Society. New York and London: Routledge. 235 p.

31. Tyulenev, Sergey. (2012b). Translation and the Westernization of Eighteenth-Century Russia. Berlin: Frank \& Timme GmbH. 272 p.

32. Varenius, Bernh. (1650) Geographia generalis. Amstelodami: Apud Ludovicum Elzevirium.

33. Weismanns 1982: Weismanns Petersburger Lexicon von 1731. Muenchen: Verlag Otto Sagner. (Reprint 1982).

$$
-327-
$$




\title{
Преодоление парадокса Просвещения
}

\author{
С. Тюленев \\ Дарэмский университет \\ Школа современных языков и культур \\ Элвет Риверсайо, Нью Элвет, Дарэм DH1 3JT
}

В статье рассматривается роль перевода в европеизации России в XVIII в. и, в частности, в процессе интеграиии российской науки в глобальную европейскую функииональную систему науки (в терминах одного из ведущих сочиологов ХХ в. Никласа Лумана). В этой глобальной системе науки перевод сыграл важную роль в преодолении парадокса, обнаружившегося в программе европейского Просвешения. С одной стороны, провозглашался необходимым международный обмен научного знания, для чего использовалась латынь, lingua franca науки того времени; с другой же стороны, доступ к знанию должен быть универсальным и внутри каждого национального государства, т.е. потенциально доступным любому, не обязательно профессионально занимающемуся наукой человеку и не обязательно владеющему латынью, a просто интересующемуся наукой и говорящему на любом из европейских национальных языков, в том числе и на русском. В качестве примеров используются документы СанктПетербургской академии наук, русские переводы научной терминологии, а также другие факты научной жизни в России XVIII в.

Ключевые слова: научный перевод, Россия, ХVIII век, Луман.

Научная специальность: 10.00.00 - филологические науки. 